UDK: $28: 343.7$

Stručni rad

Primljeno: 21. 9. 2021.

Prihvaćeno za štampu: 16.11.2021.

\author{
Dr. sc. Sulejman Topoljak, redovni profesor \\ Univerzitet u Bihaću \\ Islamski pedagoški fakultet \\ E-mail:sulejman.topoljak@hotmail.com
}

\title{
EKONOMSKO-IMOVINSKI KRIMINAL U ISLAMU
}

\section{Sažetak}

Imovina i ekonomija su osnovne potrebe svakog pojedinca, zajednice, društva i države i njihova kicma. Stoga je islam imovinu svrstao u pet univerzalnih vrijednosti, zastitio ih svojim normama i propisima i odredio sankcije protiv svakog onoga koji ib na bilo koji način ugrožava, devalvira $i$ uništava, jer se njihovom zaštitom štiti pojedinac, porodica, drustvo i javni red u dř̌avi pa i sama dř̌ava.

Imovina i ekonomija u svakom drusttvu $i$ drăavi imaju status krvotoka u živom organizmu - tijelu. Da bi tijelo bilo zdravo i moglo vršiti svoju osnovnu funkciju neophodno je da ima zdrav krvotok. Zdrav krvotok podrazumijeva zdrave i čiste vene, arterije $i$ kapilare kako bi krv mogla dopirati $i$ donositi kisik $i$ branu do svake ćelije i kapilara u organizma. Bilo koje suženje ili začepljenje u navedenim provodnicima će imati neželjene posljedice koje će se odraziti na normalno funkcionisanje tijela, a možda urrokovati i njegovu smrt. Istom logikom $i$ analogijom treba posmatrati $i$ imovinu $i$ ekonomiju u jednom drustvu $i$ drăavi. Ukoliko imovina ne bude dopirala zdravim $i$ nezačepljenim putevima do svakog gradanina $u$ drustvu $i$ rajednici, nego se bude gomilala u rukama pojedinaca ili privilegovanih grupacija i oligarbija, krvotok takva društva i države će postati bolestan i začepljen, pa takva drǒ̃ava $i$ društvo né́e moći normalno funkcionisati i onda je samo pitanje dana kada ce dobiti srčani ili moždani udar i ostati osakaćeno, potpuno paralisano ili unisteno.

Odatle je $i$ cilj ove studije da istrą̧i stav islama po pitanju ekonomsko-imovinskog kriminala i preventivne mjere koje je propisao kako bi taj krvotok qaśtitio i očuvao zbog njegove sudbonosne i nezaobilazne važnosti kako u životu pojedinca tako i u opstanku svakog društva i države. Savremena poreméenost imovinsko-ekonomskog sistema, tj. ekonomskog krvotoka na makro i mikro planu poturduje vaそ̌nost njegove 
zaštite $i$ zdravlja. U protivnom, posljedice njegove bolesti $i$ začepljenja ispaštat će, na globalnom nivou, skoro svaka drăava i svaki stanovnik ove planete. To potvrduje današnje ekonomsko stanje u svijetu i sve posljedice koje je ono urrokovao i donijelo.

U radu će biti pobrojane najva:̌nije vrste tog kriminala, sankcije koje su propisane, blagodati koje se realizuju od primjene tib sankcija, te preventivno-reformatorski program koji je islam propisao za zaštitu ekonomije i njene revitalizacije.

Ključne riječi: islam, kriminal, sankecija, borba, prevencija, imovina, program.

\section{Uvod}

Generalno se može konstatovati da su ljudska pohlepa, egoizam, materijalizam i kamatni sistem predvođeni sekularizmom glavni uzroci savremene nepravedne raspodjele prirodnih resursa, ekonomskih kriza, ratova, gladi, migracija i svih globalnih problema. Globalizacija je donijela čovječanstvu nuspojave koje se brže šire od bilo čega drugog, koje se konstantno proširuju i uvezuju. Tipične pojave globalizacije su: organizovani kriminal, korupcija, neoliberalizam kao fašizam, lobiranje tj. podmićivanje, nepotizam kao koruptivna mreža zbog koje, npr., vrhunski stručnjak u nekoj oblasti ne može doći do zaposlenja ukoliko nije član nekih vladajućih partija ili lobija. Svjetski resursi i ekonomija danas su u raljama svetog trojstva kojeg je stvorila globalizacija, a sačinjavaju ih: vlasnici kapitala, nedemokratski sistemi i mafija. Oni su potpuno uvezani (u sprezi) i funkcionišu kao jedan organizam.

Nebeske vrijednosti, kao crvene linije moralnih vrijednosti, su već odavno pređene i bezobzirno prekršene. Parametri vrednovanja moralnih i svih drugih vrijednosti su se uveliko poremetile na makro i mikro razini i potpuno obrnule. Savremeni čovjek, kao misijsko biće, umjesto da radi na izvršavanju svoje misije - uspostavi reda i pravde $u$ kosmosu, umislio je sebi da je Bog i da se ima pravo miješati u sve zakonitosti kosmosa, te svijet kreirati po svojim uskim interesima, pohlepi, egoizmu i nasilju. Takve percepcije kosmosa su iznjedrile globalizaciju tj. potčinjavanje ljudi lažnim božanstvima, njihovim vrijednostima, potisnule iz javnog života istinskog i pravog Boga i nebeske vrijednosti. Savremenim svijetom danas upravlja nekoliko multimilijardera koji kreiraju religiju globalizma, vladaju svijetom i nameću im svoja pravila igre koja u biti imaju status nove religije. Kreatori globalizacije su, ustvari, savremena božanstva koja niko ne 
pita šta rade, a sve ostale pitaju i žestoko kažnjavaju ukoliko postupe suprotno naputima i obredima novih lažnih božanstava.

Islam svojim sankcijama, čija je svrha zaštita pet univerzalnih ljudskih vrijednosti, ima za cilj da zaštiti i prevenira pojedinca i društvo, kako ne bi došlo do navedenih pojava, te spriječi svakog koji pokuša da bespravno suzi bilo koji protok imovinsko-ekonomskog krvotoka u društvu i zajednici ili ga želi potpuno začepiti i na taj način uništiti i staviti pojedinca ili društvo pod svoju kontrolu.

Krivično pravo u islamu je isključivo u ingerenciji država, te stoga niko drugi nema suverenitet da ga primjenjuje. Njegova primjena je jedno od najvećih dobrih djela čije posljedice osjećaju svi na Zemlji. Zato je s pravom rečeno da je primjena jedne šerijatske kazne na Zemlji bolja od padanja kiše četrdeset dana, aludirajući na blagodati i pravdu koju donosi primjena Božijeg zakona na planeti za sve njene stanovnike.

Neophodno je danas istaći da se šerijatsko krivično pravo, nakon uspostave islamske države, primjenjuje zadnje $\mathrm{u}$ odnosu na ostale segmente islama i pravnih normi i propisa. Ono je, ustvari, samo jedan učinkoviti instrument putem kojeg se štiti pravda, javni red i moral u državi i društvu nakon što se oni uspostave. Njegova primjena prije svega bi bila besmislena ukoliko prije toga država ne obezbijedi ljudima osnovne ljudske potrebe i zaštiti ljudsko dostojanstvo. U takvim društvima bi bilo zabranjeno primjenjivati šerijatsko krivično pravo, jer njegovom primjenom se ne bi realizovali ciljevi i intencije zbog kojih je ono i propisano, te bi se kazne provodile nad onima kojima nisu namijenjene $\mathrm{i}$ onda bi u njemu nastao nered, smutnja $\mathrm{i}$ nepravda.

\section{Prvi dio}

Kriminalom ili zločinom u islamu se smatra svaka šerijatska zabrana ili apstiniranje naređenog djela, čijeg počinioca ili prestupnika islam sankcionira s fiksnom - haddom ili diskrecionom kaznom t'azirom.

U osnovi, musliman je obavezan u sredini u kojoj živi biti političan tj. da poziva ka dobru i ustaje protiv zla pa mu je samim tim apolitičnost strana. Tu činjenicu potvrđuju osnovni izvori islama. 
Uzvišeni je rekao: I neka među vama bude onih koji će na dobro pozivati i tražiti da se čini dobro, a od zla odvraćati - oni će šta žele postići. (Ali Imran, 104)

Poslanik, a.s., nas je upozorio da ne smijemo biti politički indolentni u sredinama gdje se nađemo rekavši: „Ko od vas vidi neko zlo neka ga promijeni rukom, ako ne može rukom, neka to učini jezikom a ako ne može ni jezikom onda srcem, ali je to najslabiji iman." ( Muslim, br. 49)

\section{Najpoznatiji imovinsko-ekonomski zločini i njihove sankcije u islamu}

Težina sankcije $\mathrm{u}$ islamu je propisana ekvivalento veličini zločina $\mathrm{i}$ opasnosti njegovih posljedica koje se reflektuju na pojedinca, društvo ili zajednicu. Stoga, sve što je zločin veći i što su mu posljedice opasnije utoliko su i sankcije za njegove počinioce teže i rigoroznije. Svaka sankcija u islamu mora ispunjavati dva osnovna uvjeta: da bude zadžire - poučna i džabire - kompenziona.

\section{1. - Zločin krađe i propisana sankcija}

Pod krađom se u islamu podrazumijeva svako bespravno i tajno uzimanje tuđe imovine s mjesta gdje se ona obično čuva. ${ }^{1}$ Krađa je u islamu zabranjena jer predstavlja jedan vid bespravnog uzimanja tuđe imovine. To potvrđuje Kur'an i sunnet.

Uzvišeni Allah je rekao: Kradljivcu i kradljivici odsijecite ruke njihove, neka im to bude kazna za ono što su učinili $i$ opomena od Allaha! A Allah je silan i mudar. (El-Maide, 38)

Poslanik, a.s., je rekao: „Allah je prokleo kradljivca koji ukrade makar jedno jaje ili uže pa mu se zbog toga odsiječe ruka." (Buharija, br. 6783, 6799)

Islam je za krađu propisao odsijecanje ruke, a Poslanik, a.s., je to i u praksi sprovodio. Vjerodostojno se prenosi da je odsjekao ruku nekoj

\footnotetext{
${ }^{1}$ Serahsi, El-Mebsut, Knjiga o krađi str. 133. Serahsi navodi da postoje dvije vrste krađe: Velika i mala. Vidi: Abdulkadir Avdeh, Et-Tě̌ri'ul-džinail-islami mukarenen bil-kanunil-ved'i, 2/514., muessesetur-risale, 7. izdanje, 1406. po H. /1986. god.
} 
Ženi iz plemena Mahzum pa je njen slučaj poznat kao slučaj Mahzumijje. Kada se Usame b. Zejd htio zauzeti za nju da joj se ne odsiječe ruka, Poslanik, a.s., mu je rekao: „Oni koji su bili prije vas su propali zbog toga što kada bi neko među njima od uglednih ukrao ne bi mu odsijecali ruke, a kada bi to uradio neki obični čovjek odsijecali bi mu ruku. Tako mi Onoga u čijoj je ruci moj život, da Fatima, Muhammedova kćerka, ukrade odsjekao bih joj ruku." (Buharija, br. 6788, 3475)

Kradljivcu će pokajanje biti primljeno, samo ukoliko vrati ukradeno vlasniku, ${ }^{2}$ a ako to ne mogne učiniti zbog materijalne nemoći itd., obavezan je tražiti halala od istog, tj. vlasnika ukradene imovine. A ako vlasnik nije poznat, onda će podijeliti sadaku na ime vlasnika imovine u iznosu ukradenog imetka. ${ }^{3}$

Primjena kazne za krađu ima velike koristi i pozitivne implikacije na društvo i zajednicu u kojima se ona primjenjuje. Prije svega, štiti živote, imovinu i sigurnost građana i cjelokupne zajednice. U isto vrijeme, preventivno djeluje i na svaki oblik krađe i profiterstva. Kada se kazna za krađu primjenjivala, broj krađa enormno je smanjen, blagostanja i berićet su zavladali islamskom državom, a ekonomske i imovinske transakcije su bile sigurne i neupitne pa je blagodati od njene primjene osjetilo cijelo društvo.

U savremenom svijetu danas se direktna i posredna krađa $u$ ekonomskim transakcijama širi epidemijskim razmjerama. Najopasnije i najnepravednije u svemu tome jest to što povlašteni, organizatori i planeri velikih krađa i krađa svjetskih razmjera ostaju zakonu nedodirljivi, a kažnjavaju se i zatvaraju oni koji su prisiljeni na krađu i koji iz nužde i velike potrebe uzimaju minimalno od onoga što su im prvi oteli i uzeli kako bi mogli prehraniti sebe i svoje porodice. Islam u takvim situacijama nalaže da se tjeraju, gone i zatvaraju oni koji su prisilile druge na krađu zbog toga što su im bespravno direktno ili posredno oteli njihova prava.

\footnotetext{
${ }^{2}$ El-Mevsatul-fikhijje, 17/134.

${ }^{3}$ Nevevi, El-Medžmu, 9/351-352.
} 
Kazna za krađu u islamu je odsijecanje desne ruke onome koji prvi puta ukrade, a ako se desi recidiv, onda se odsijeca lijeva noga i tako naizmjenično po relevantnim mišljenjima nekih islamskih pravnika. ${ }^{4}$

\section{2. - Zločin utaje i propisana sankcija}

Pod zločinom utaje se podrazumijeva kada službenici, radnici i ostali činovnici na radnom mjestu bespravno utaje javnu imovinu i ostala javna dobra. To je jedna vrsta krađe koja spada u kategoriju bespravnog uzimanja tuđe imovine. Utaja je uveliko raširena u državnim firmama, institucijama, javnom i privatnom sektoru, a posebno u pokretnoj imovini poput, raznih roba, sirovina, te raznovrsnih zamjenskih dijelova, novca, itd. Isto tako, utaja je raširena i u humanitarnim organizacijama, vjerskim zajednicama i raznim fondacijama. Utaja javne imovine dovodi do njenog uništenje i podriva stabilnost društva i zajednice, te doprinosi širenju nemorala $u$ finansijskim transakcijama.

Nad onima koji počine ovu vrstu kriminala islam je propisao kaznu za krađu ili adekvatnu diskrecionu kaznu, sukladno različitim mišljenjima islamskih pravnika koja su detaljno elaborirana u djelima islamskog prava, ukoliko se ispune uvjeti za primjenu kazne za krađu. ${ }^{5}$

\section{3. - Zločin pronevjere emaneta i propisana sankcija}

Pod pronevjerom emaneta $u$ ekonomsko-imovinskim transakcijama se podrazumijeva svako bespravno prisvajanje i zloupotreba povjerenih emaneta i stvari koji su namještenicima povjereni i dati na korištenje na osnovu njihovih zvanja, funkcija, stručnih sprema, specijalizacija, itd. Ta zloupotreba može biti učinjena aktivno u ekonomsko-imovinskim transakcijama - neposredno ili pasivno - posredno putem podržavanja, navođenja, odobravanja i prešućivanja, itd.

Islam je takvu praksu strogo zabranio i naredio da se pronevjereni emaneti moraju vratiti njihovim vlasnicima. Uzvišeni je rekao: $A$ ako jedan kod drugog nešto pohranite, neka onaj opravda ukazano mu povjerenje i neka se boji Allaha. (El-Bekare, 283)

\footnotetext{
${ }^{4}$ Ibn Kudame, El-Mugni, 10/264., prvo izdanje, Darul-fikri, Bejrut, 1984. god.

${ }^{5}$ Serahsi, El-Mebsut, Knjiga o krađi str. 264-265.
} 
Islam je generalno zabranio pronevjeru svakog emaneta: $O$ vjernici, Allaha $i$ Poslanika ne varajte $i$ svjesno međusobno povjerenje ne proigravajte. (El-Enfal, 27)

Poslanik, a.s., je strogo zabranio pronevjeru emaneta i rekao: „Čuvajte se pronevjere emaneta jer je to loš drug." (Albani, Da'ifut-tergib, br. 1347)

Pronevjera emaneta se smatra jednim od svojstava licemjerstva na šta je Poslanik, a.s., ukazao u sljedećem hadisu: „(...) kada mu se šta povjeri pronevjeri i kada obeća ne ispuni.“ (Buharija, br. 6095 i Muslim, br. 59)

Od najrasprostranjenijih oblika pronevjere u ekonomsko-imovinskim transakcijama i ostalim segmentima su:

- zapošljavanje nestručnih i nemoralnih osoba na osnovu stranačke pripadnosti, podobnosti, nepotizma i pored postojanja onih koji su sposobniji, stručniji i moralniji. Poslanik, a.s., je rekao: „Ko zaposli nekoga u nekom mjestu, a u njemu među ljudima ima onih s kojima je Allah zadovoljniji, tj. koji su sposobniji i kompetentniji, iznevjerio je Allaha, Njegova Poslanika i sve vjernike." (Albani, Da'ifut - Tergib, br. 1339, Daiful-Džam'i, br. 54301)

- namjerno namještanje tendera i ponuda određenim osobama i firmama zbog nekih ličnih interesa i pored postojanja onih koji su dali bolju i povoljniju ponudu.

- uzimanje određenog procenta od zainteresovane strane zbog olakšavanja i namještanja nekih poslova bez znanja vlasnika firme, institucije itd. Ovo je jedan vid mita koje je islam strogo zabranio i na koga se odnosi sljedeći hadis: „Allah je prokleo onoga koji daje mito, ko ga prima i ko posreduje u njemu.“ (Ibn Hibban, br. 5077, Ahmed, br. 6778, 6779, 6830)

- lažna svjedočenja, usmena ili pismena, za nekoga da, npr., dobije neku privilegiju, benefit ili materijalnu dobit na koji nema pravo kao što je lažno svjedočenje ili potpisivanje izvještaja da je neko ispunio uvjet za određeno akademsko zvanje, ili da je kompetentan za neku funkciju, a ustvari niti je stekao uvjete za traženo zvanje, niti je kompetentan za određenu funkciju, ili svjedočenje da je neki poslodavac solventan i da redovno isplaćuje svoje obaveze kako bi 
dobio neke olakšice a ustvari nije, ili da neki potpis ili dokument krivotvori ili kupi diplomu kako bi postigao neke privilegije, funkcije i benefite na koje nema pravo. Uzvišeni Allah je zabranio lažno svjedočenje i rekao: I oni koji ne svjedoče lažno, i koji, prolazeći pored onoga što ih se ne tiče, prolaze dostojanstveno. (El-Furkan, 72)

Isto tako je Poslanik, a.s., upozorio na lažno svjedočenje rekavši: „Hoćete li da vas obavijestim o najvećim grijesima,“ ponavljajući to tri puta. Rekli smo da hoćemo pa je rekao: „Politeizam - širk, neposlušnost roditeljima, a bio je nasloljen pa je sjeo, i lažan govor i lažno svjedočenje“", kontinuirano je to ponavljao da smo rekli kamo sreće da prestane.“ (Buharija, br. 5977 i Muslim, br. 88)

- neracionalno korištenje namjenske imovine i sredstava kao npr. da se neka mašina ostavi pokvarena ne nastojeći je popraviti, ostavljanje nekih sirovina da se pokvare, neodgovorno ponašanje ili vožnja koja uzrokuje kazne ili materijalne kompenzacije, korištenje materijalnih sredstava u nenamjenske svrhe, itd. Svi navedeni i njima slični oblici odnosa prema povjerenoj imovine se smatraju pronevjerom emaneta zbog zajedničkog zakonskog razloga propisa - uništavanja imovine što je zabranjeno u islamu. Poslanik, a.s., je rekao: „Allah vam je zabranio uništavanje imovine.“ (Buharija, br. 5975, Muslim, br. 593)

Kazna za pronevjeru emaneta $\mathrm{u}$ islamu je fiksna kod pravnika koji tom zločinu daju status krađe. A oni koji smatraju da pronevjera emaneta nema status krađe, kazna je tazir - diskreciona gdje sud odabire adekvatnu kaznu koja mora biti ez-zadžire - poučna za sve ostale koji namjeravaju krenuti putem pronevjere emaneta da ih ona odvrati od toga, i el-džabire - kompenziona, $\mathrm{tj}$. da se pronevjera imovine mora nadoknaditi, te da se na taj način sačuvaju prava u imovini koja su narušena neodgovornim ponašanjem. ${ }^{6}$

\section{4. - Zločin kršenja ugovora ili obećanja i propisana sankcija}

Pod zločinom kršenja ugovora i obećanje u imovinsko-ekonomskim transakcijama se podrazumijeva neispunjavanje dogovora i obećanja, ili namjerno odugovlačenje i neispunjavanje onoga oko čega su se

\footnotetext{
${ }^{6}$ Izduddin Belik, Minhadžus-salihin, babu hududillahi fi himajetil-mudžteme'i. str. 570., Darul-fethi, Bejrut, 1398. po H./1987. god, Mevsuatul-fikhijje, 12/258.
} 
ugovorači dogovorili ili, svjesno i namjerno odstupanje od dogovorenih projekata radi uštede i zarade, itd. Svi navedeni i njima slični oblici kršenja ugovora i obećanja po šerijatu su strogo zabranjeni.

U Kur'anu su mnogobrojni ajeti koji stimulativno podstiču na poštivanje ugovora i obećanja i njihovu realizaciju.

Uzvišeni je rekao: I ispunjavajte obavezu, jer će se za obavezu, zaista, odgovarati! (El-Isra, 34) I ne budite kao onā koja bi svoju pređu rasprela kad bi je već bila čvrsto oprela. (En-Nahl, 92)

U tom smislu je Poslanik, a.s., izrekao mnogobrojna upozorenja i savjete svojim sljedbenicima od kojih su: „Ko imadne s nekim ugovor neka ga ne krši a niti otežava, ili neka ih obavijesti o njegovom prekidu.“ (Ibnul- Arabi, 'Aridatul-ahvezi, 3/322); „Kod koga se nađu četiri svojstva pravi je licemjer, a kod koga se nađe jedno od njih, ima kod sebe jedno svojstvo licemjera sve dok ga ne ostavi. Ta svojstva su: kada govori laže, kada mu se nešto povjeri pronevjeri, kada obeća ne ispuni i kada se prepire pređe granicu.“ (Buharija, br. 6095, Muslim, 59); „Odgađanje vraćanja duga od strane bogatog je nasilje.“ (Buharija, br. 2400, Muslim, br. 1564)

Neki od oblika kršenja ugovora i obećanja u imovinsko-ekonomskim transakcijama:

- nepoštivanje radnog vremena tj. nedolazak na vrijeme na posao $\mathrm{i}$ odlazak s posla prije vremena;

- uzimanje neopravdanog bolovanja radi izbjegavanja posla i dobivanje opravdanja za izostanak;

- nepoštivanje ugovorenih rokova za realizaciju preuzetih obaveza i obećanja;

- izbjegavanje primjene zakona i propisa putem raznih manipulacija i pravnih doskočica kako bi se izbjeglo izvršenje preuzetih obaveza i obećanja;

- svjesno i namjerno odgađanje vraćanja dugova i tuđih prava.

Neizvršavanje ugovora i preuzetih obaveza i obećanja implicira opći nered u imovinsko-ekonomskim transakcija koji se reflektuje i na cijelo društvo jer se na taj način atakuje i vrši agresiju na javnu i privatnu imovinu. Ova vrsta imovinskog kriminala je posebno raširena $i$ 
zastupljena u državnim institucija, školama, univerzitetima, državnim firmama i preduzećima čime se uzrokuje ogromna šteta po društvo, zajednicu i državu.

Kazna koju je islam propisao za ovu vrstu ekonomskog kriminala je diskreciona koja, po nekim pravnicima, može dostići i stepen smrtne kazne. Nadležni trebaju procijeniti i odabrati adekvatnu kaznu za navedene zločine sukladno stanju počinioca, veličini kriminala, mjestu, vremenu i njegovoj raširenost u društvu i zajednici uvažavajući naprijed navedena dva uvjeta koja svaka diskreciona kazna mora ispuniti. ${ }^{7}$

\section{5. - Zločin rasipništva i uništenja javne imovine i propisana sankcija}

Pod ovom vrstom imovinsko-ekonomskog zločina se misli na upotrebu imovine ili novca čiji je krajnji ishod njegovo uništenje ili zloupotreba, koja ima status ataka i agresije na javnu imovinu. Ukoliko se to desi nenamjerno, onda počinilac nema odgovornosti, u suprotnom je zabranjeno i kažnjivo. Uništenje imovine ili njeno pretjerano i neracionalno trošenje se smatra jednim vidom pronevjere emaneta $\mathrm{i}$ agresije na nju. ${ }^{8}$

Ova vrsta ekonomskog kriminala posebno dolazi do izražaja onda kada dođe vrijeme njena popisa i inventure. Tada se imovina nezakonito uništava ili otpisuje kako bi se prekrile naznake krađe, utaje i pronevjere. A najpoznatiji oblici takvog kriminala su izazivanje požara u magacinima ili njihovo potapanje vodom, ili uništenje dokumentacije i registara.

Kazna za uništenje imovine i njeno rasipanje može biti fiksna, ali i diskreciona sukladno idžtihadu nadležnih. Neki islamski pravnici ovu vrstu ekonomskog kriminala svrstavaju u činjenje nereda na zemlji, tj. razbojništvo zašto je propisana fiksna kazna, a neki opet smatraju da se počinitelji navedenog zločina kažnjavaju diskrecionom kaznom zavisno od njegove raširenosti u državi i društvu. ${ }^{9}$

\footnotetext{
${ }^{7}$ Mevsuatul-fikhijje, 12/263.

8 Muhhamed Abdulhalim, Omer, Er-Rekabetu alel-emvalil-ammet, str. 157., Tidžaretul-ezher, 1979. god.

${ }^{9}$ Mevsutaul-fikhijje, 12/277.
} 


\section{6. - Zločin neodgovornosti i neprofesionalnosti i propisana kazna}

Pod ovom vrstom ekonomskog kriminala se misli na nemarnost i nebrigu pri vršenju posla što ima za posljedicu loše i nekvalitetne proizvode i učinke. Razlog tome treba tražiti u dva faktora: prvi je neposjedovanje dovoljno iskustva, kompetentnosti i profesionalnih mogućnosti kod odgovornih i radnika, a drugi je nemarnost i nebriga za posao koji se obavlja. Oba razloga se smatraju atakom na imovinu što ima za posljedicu njeno uništenje i nestanak.

Sve navedeno islam je strogo zabranio.

Uzvišeni je naredio da se poslovi obavljaju na najbolje način rekavši: One koji budu vjerovali i dobra djela činili-Mi doista nećemo dopustiti da propadne nagrada onome koji je dobra djela činio. (El-Kehf, 30)

Isto tako je Poslanik, a.s., ukazao i podstakao na perfekcionizam i kvalitet u poslu i funkciji rekavši: „Uistinu Allah voli kada neko od vas radi neki posao da ga upotpuni i usavrši." ( Bejheki, Albani, Sahihah, br. 1113)

Nestručnost, nebriga i nemarnost stvara poremećaj u ekonomskom poslovanju i transakcijama te dovodi do gubljenja povjerenja među partnerima, kao što uzrokuje štetu, uništenje i nestanak imovine i ljudi.

Kazna za navedenu vrstu ekonomskog kriminala može biti fiksna kazna za krađu ili diskreciona, sukladno prilikama i situacijama u kojima se on čini ili počini. ${ }^{10}$

\section{7. - Zločin izbjegavanja izvršenja društvenih obaveza i propisana sankcija}

Islamsko pravo u datim okolnostima daje pravo državi ${ }^{11}$ da nametne neke obaveze na privatnu imovinu poput pravednih poreza, nekih vrsta dadžbina, taksi itd. Izbjegavanje plaćanja i izvršenja ovakvih i sličnih obaveza smatra se zločinom za koji se kažnjava onaj ko ih izbjegava.

\footnotetext{
${ }^{10}$ Mevsutaul-fikhijje, 12/277.

${ }^{11}$ Gazi Inajeh, El-Malijetul-ammetu ven-nizamul-malil-islami, dirasetun makarenetun, str.359., Darul - džejl, Bejrut, 1410. po H./11990. god.
} 
Pri propisivanje navedenih obaveza moraju se ispuniti sljedeći uvjeti:

1. - da u propisivanju navedenih obaveza nema nečega što je oprečno načelima islama $\mathrm{i}$ intencijama šerijata, jer javni interes koji se smatra pomoćnim izvorom šerijata mora biti sukladan intencijama šerijata, $\mathrm{u}$ protivnom se ne može prihvatiti kao dokaz tj. za pomoćni izvor.

2. - da nametanje takvih obaveza i dadžbina bude pravedno i opravdano, te da onaj koji ubire poreze bude pravedan. U protivnom, musliman ima pravo da ih odbije i to odbijanje bi imalo status zaštite lične imovine što je po šerijatu dozvoljeno. Općepoznato je da onaj koji pogine braneći svoju imovinu, ima status šehida.

3. - da država svoje službenike koje imenuje za sprovođenje navedenih nameta i poreza obaveže da se pridržavaju islamskih normi i propisa koji regulišu taj segment ljudskog života, te da te obaveze izvršavaju bez nasilja, nepravde, maltretiranja i ponižavanja. U protivnom će svjesno ili nesvjesno slabiti državu i nacionalni osjećaj kod njenih građana. I ovo spada u domen odgovornosti države prema svojim podanicima.

Pri propisivanju pravednih poreza i ostalih nameta moraju se uvažiti sljedeće činjenice:

- da postoji istinska potreba za imovinom, a u isto vrijeme ne postoje drugi izvori iz kojeg bi se taj deficit sanirao i pokrile nužne potrebe;

- da se porezi ravnomjerno i pravedno rasporede na sve bogate;

- da se troše za opći interes, a ne u nered i zabranjene stvari ili privatne svrhe i prohtjeve;

- da njihovo nametanje odobri vijeće za savjetovanje - šura i vijeće za imenovanje i razrješenje službenika - ehlul - akdi vel-halli;

- da se troše u one svrhe koje su ih inicirale i radi kojih su i nametnuti;

- da se nametnu samo bogatima, a ne i siromašnima;

- da se ukinu nakon što prestane potreba za njima. ${ }^{12}$

12 Muhamed Abdulhalim, Omer, Er-Rekabetu alel-emvalil-ammet, str. 1079-1088., Tidžaretul-ezher, 1979. god. 
Kazna za izbjegavanje nametnutih društvenih obaveza od strane država $\mathrm{u}$ islamskom pravu je diskreciona koju nadležni trebaju propisati sukladno stanju i prilikama u kojima se oni počine / čine.

\section{8. - Zločin mita i korupcije i propisana sankcija}

Islamski pravnici su saglasni oko zabrane uzimanja i davanja poklona i sličnoga službenicima i namještenicima zbog funkcije koju obnašaju jer se to smatra jednom vrstom mita i jednim vidom pronevjere emaneta.

Kur'an je to osudio rekavši: Nezamislivo je da Vjerovjesnik šta utaji! A onaj ko nešto utaji - donijeće na Sudnji dan to što je utajio. (Ali Imran, 161)

Pod utajom se u ajetu aludira na utaju ratnog plijena prije njegove službene podjele, ili privilegovanje nekog u davanju javne imovine na račun drugog, kao što se ponekad dešava kod podjele raznih nagrada, podsticaja, zahvala, odlikovanja, promovisanja itd.

Najpoznatiji savremeni oblici mita i korupcije u imovinskoekonomskim transakcijama su:

- otkrivanje poslovnih tajni od strane službenika nekom ko će se okoristiti od njih i zaraditi. $\mathrm{Na}$ taj način se bespravno privileguje neko na račun drugog. Takva praksa ima status pronevjere emaneta.

- falsifikovanje nekih dokumenata od strane službenika s ciljem da sebi namakne neki interes ili materijalnu dobit ili nekome drugom kome to treba, na štetu institucije u kojoj radi kao npr. promjena satnice dolaska i odlaska s posla, količine proizvedene robe itd. Ovakva praksa ima status jedenja harama - es-suhta.

- korištenje svoje funkcije, položaja i raznovrsnih mogućnosti da direktno ili indirektno pribavi sebi zaradu, ugled, korist itd. kao primanje i zapošljavanje svojih bližnjih, rodbine i poznanika itd., ili razne vrste drugih usluga koje mu stoje na raspolaganju zbog funkcije koju obnaša i položaja na kom se nalazi.

- korištenje svog položaja ili vlasti kod donošenja pozitivnih ili negativnih odluka kako bi mogao namaknuti sebi neki nelegalan interes ili korist iz privatne imovine ljudi, ili npr. da se džaba vozi javnim 
prevozom, da koristi službeno auto za privatne svrhe, ili da (is)koristi neke stvari svojih podređenih za svoje lične interese i šićare.

Navedeni i slični ekonomski kriminal islamski pravnici svrstavaju u pronevjeru emaneta i bespravno poništenje ugovora o radu, a naprijed su navedeni dokazi koji jasno potvrđuju da su takvi poslovi po islamu strogo zabranjeni.

Kazna koju je islam propisao za ovu vrstu kriminala je fiksna ili diskreciona sukladno prirodi zločina i okolnostima u kojima je počinjen ili se čini.

\section{9. - Zločin agresije na javnu imovinu i propisana sankcija}

Islam načelno dozvoljava pluralnost mišljenja, političkih partija i nadmetanje među njima. Međutim, strogo zabranjuje zloupotrebu i iskorištavanje javne imovine za finansiranje svake vrste izbora, te naređuje da se to finansiranje treba realizovati iz privatne imovine same stranke.

Imam ili predsjednik države je odgovoran za nadzor trošenja i zaštite javne imovine i pred Bogom i pred narodom.

Ono što se, nažalost, dešava u mnogim muslimanskim državama je, da vladajuća partija iskoristi sve vrste javne imovine: pokretne i nepokretne u svrhu finansiranja svoje izborne kampanje i izbora, smatrajući da na taj način radi opće dobro i korisno djelo za narod, a ustvari čini zabranjeno djelo - krađu i otimačinu javne imovine.

Analogno tome, isto se može reći za vrijeme i trud službenika u javnim institucijama koji za to vrijeme napuštaju svoje osnovne obaveze kako bi uzeli učešće u predizbornim kampanjama ili podržali određenog kandidata protiv drugog, itd.

Najupečatljiviji i najopasniji primjeri su davanje podrške od strane određenih institucija poput policije, tajnih službi, sudova, ministarstava, itd. vladajućoj partiji, ili partijskom lideru, ili nekom drugom interesu pa se na taj način pod plaštom zakona krade javna imovina u vrijeme kada na stotine hiljada građana ne mogu sebi priuštiti ni osnovne životne potrebe, niti sačuvati svoje ljudsko dostojanstvo. 
Status zloupotrebe javne imovine i njeno korištenje za partijske i lične interese je zabranjeno - haram i ima status utaje i pronevjere emaneta nad čijim počiniocima se po šerijatu primjenjuje diskreciona kazna koja se procjenjuje na osnovu idžtihada nadležnih i odgovornih državnih institucija sukladno opasnosti i obimu ove vrste ekonomskog kriminala. $^{13}$

\section{0. - Zločin protekcionizma i propisana sankcija}

Jedna od najopasnijih oblika ekonomskog kriminala je i zločin protekcionizma, licemjerstva i poltronstva. Od najpoznatijih njegovih oblika je velika potrošnja javnog novca ministarstava, javnih ili privatnih institucija na poltronizam i licemjerstvo prema određenim licima poput ministara, direktora, predsjednika, itd., s ciljem dodvoravanja i pridobivanja njihove naklonosti radi realizacije nekih privatnih interesa i šićara koje islam zabranjuje.

Dokaz toga jeste da kada dotični službenik napusti funkciju ili položaj koji obnaša, automatski bude zanemaren i zaboravljen. To poltronstvo i licemjerstvo potvrđuje i činjenica da, kada nekome od navedenih funkcionera, naprimjer, neko umre naći će se na stotine izraženih saučešća u novinama i drugim informativnim sredstvima od strane službenika institucije gdje je on glavni, a kada napusti taj položaj niko se od njih više uopće ne oglašava kao da nije imao nikoga na ovome svijetu.

Ova vrsta ekonomskog kriminala je zabranjena i spada u kategoriju licemjerstva, rasipništva i zanemarivanja prioriteta kojeg je islam propisao pri trošenju javne imovine, a naročito kada se radi o siromašnim i zaduženim državama u kojima većina građana ne mogu sebi priuštiti ni osnovne životne potrebe.

Kazna koja je propisana za ovu vrstu ekonomskog kriminala je diskreciona koju nadležni određuju sukladno svom idžtihadu, te reforma svega onoga što je uzrokovao ovaj kriminal i vraćanje oduzetih prava društvu i zajednici.

${ }^{13}$ El-Mevsuatul-fikhijje, 12262-263. 


\section{1. - Zločin kamate i propisana sankcija}

U islamu ni za jedan zločin nije nagoviještena veća kazna i strašnija prijetnja, niti je ukazano na njegovu opasnosti i veličinu grijeha kao za kamatu što implicitno ukazuje na opasnost tog zločina i njegovu štetu koju reflektuje kako na pojedinca, tako i na narode, društva, države, ekonomiju pa i cijelo čovječanstvo.

Islam je kategorički zabranio sve vrste kamatnih transakcija, a Allah objavljuje rat svima onima koji ih upražnjavaju i konzumiraju rekavši: $O$ vjernici, bojte se Allaha i od ostatka kamate odustanite, ako ste pravi vjernici. Ako ne učinite, eto vam onda, neka znate - rata od Allaha $i$ Poslanika Njegova! (El-Bekare, 278-279)

Bavljenje kamatom se smatra jednim od sedam najvećih grijeha kako je to navedeno u sljedećem hadisu: „Klonite se sedam najvećih grijeha.“ Upitali su: „Koji su to Allahov Poslaniče?“ Rekao je: „Pripisivanje Allahu sudruga, sihr, bespravno ubijanje, jedenje kamate, jedenje jetimskog imetka, bježanje s bojnog polja i potvaranje poštenih i časnih vjernica.“ (Buharija, br. 2766 i Muslim, br. 89)

Kamatne transakcije vode ka ekonomskoj nestabilnosti i uzrokuju poskupljenje života, povećanje cijena, gomilanje bogatstva u rukama pojedinaca, te inflaciju i deflaciju. Isto tako kamata uzrokuje $\mathrm{i}$ sustezanja investitora od različitih invensticionih projekata ukoliko njihova dobit bude manja od kamate.

U tom smislu Sejjid Kutb je rekao: „Pa, eto, mi smo ti koji vidimo da nema nijednog društva koje operiše kamatom, a da u njemu ostaje blagoslov, blagostanje, sreća, sigurnost i smirenost... Allah uništava kamatu, pa, prema tome, na to društvo u kome se susreće takva prljavština, izliva samo nesreću. Oko primjećuje, s formalne strane, blagodat, proizvodnju i obilne prihode, međutim, blagodat ne dostiže stepen ugodnog i sigurnog uživanja u odnosu na visinu tih prihoda. Ukazali smo i na društveni nemir koji ne može da odagna bogatstvo, štaviše, ono povećava taj nemir. Iz ovih zemalja izliva se taj nemir, strah i uznemirenost, danas, na cio svijet, tako da čovječanstvo živi u stalnoj prijetnji razornih ratova. Čovječanstvo liježe i ustaje u strahu od rata koji sve uništava. Taj strah od rata pritiskuje život, opterećuje nerve 
ljudi iz dana $u$ dan, bilo da oni osjete ili ne osjete. Ne uživaju ni $u$ sredstvima, ni u životu, ni u zdravlju, ni u miru. “14

Islamski pravnici su saglasni da je svaki oblik konvencionalne i savremene kamate zabranjen $\mathrm{u}$ islamu.

Kazna kojom se sankcionira ovaj ekonomski zločin je diskreciona koju sukladno prilikama i situaciji određuju nadležni. A konzument ovog zločina može imati status otpadnika ukoliko smatra da je on dozvoljen i nužan za današnje imovinsko-ekonomske transakcije jer je odbio priznati nešto što je opće i nužno poznato u islamu i onda se nad njim primjenjuju propisi za otpadništvo gdje mu se daje prilika tri dana, da se pokaje, tj. vrati u islam.

\section{2. - Zločin alkohola i opojnih sredstva i propisana sankcija}

Proizvodnja, trgovina i služenje alkohola i ostalih opijata u islamu se smatra zločinom koji je islam strogo osudio i zabranio zbog toga što ih smatra izvorima zla, grijeha, nereda, propasti i uništenja. Kada kod čovjeka nestane razuma, kada se on pomuti ili blokira spreman je uraditi bilo šta i nanijeti štetu sebi samom, drugima, imovini i ekonomiji.

Uzvišeni Allah je naredio da se klonimo alkohola rekavši: O vjernici, vino $i$ kocka $i$ kumiri i strjelice za gatanje su odvratne stvari, šejtanovo djelo; zato se toga klonite da biste postigli što želite. Šejtan želi da pomoću vina i kocke unese među vas neprijateljstvo i mržnju i da vas od sjećanja na Allaha i od obavljanja molitve odvrati. Pa hoćete li se okaniti? (El-Maide, 90-91)

Poslanik, a.s, je rekao: „Vino je samo po sebi prokleto, a prokleti su i: oni koji ga piju, koji ga toče, koji ga prodaju, koji ga kupuju, koji ga cijede, kojima se cijedi, koji ga nose, kojima se nosi i koji žive od njegove prodaje." (Ebu Davud, br. 3674, Ahmed, br. 5716, Albani, Sahihul-Džami'u, br. 5091)

Alkohol uzrokuje ekonomsku nestabilnost i nered jer se putem njega atakuje i vrši agresija na razum čija je osnovna funkcija da razmišlja, upućuje i donosi odluke, a pijana osoba izlaže sebe, svoju imovinu i

${ }^{14}$ Seyyid Qutb, U okrilju Kur'ana, 3/88-89. Fakultet islamskih nauka, Oko Sarajevo, 1997. god. 
cijelu zajednicu propasti. Savremene službene statistike u skoro svim zemljama svijeta potvrđuju da je alkohol glavni uzrok svih zločina koji se dese. ${ }^{15}$

Kazna koju je islam propisao za konzumiranje alkohola je fiksna u iznosu od osamdeset bičeva i propisana je sunnetom, a njen iznos konsenzusom. ${ }^{16}$ A svi propisi i norme koje se odnose na alkohol odnose se i na sve ostale opijate i droge.

\section{3. - Zločin kocke hazarda i propisana sankcija}

Kocka je jedna vrsta ekonomskog kriminala koji ostavlja veoma loše posljedice na ekonomiju, društvo i moral, te odvraća od proizvodnje i korisna rada. Pored toga, kocka je i jedan vid bespravnog uzimanja tuđeg imetka. Ona je u islamu zabranjena Kur'anom, sunnetom i konsenzusom.

Uzvišeni je rekao: O vjernici, vino i kocka i kumiri i strjelice za gatanje su odvratne stvari, šejtanovo djelo; zato se toga klonite da biste postigli što želite. (El-Maide, 90)

Poslanik, a.s., je rekao: „Ko rekne svom drugu: Dođi da se kockamo, neka podijeli sadaku." (Buharija, br. $7 \longleftarrow \cdot 1$, Muslim, br. 1 $7 \varepsilon v$ )

Islamski pravnici su saglasni da je kocka zabranjena definirajući je kao klađenje u nešto što je neizvjesno. ${ }^{17}$

S ekonomskog aspekta kocka uzrokuje gubljenje vremena bez ikakve legalne koristi, beskorisno uništenje imovine i poremećenost $u$ ekonomiji bez ikakvog ekonomskog opravdanja. Islam je zabranio mnoge transakcije koje počivaju na kocki poput lutrije i svih vrsta klađenja i hazardnih igara. Mnogobrojne svjetske burze su doživjele krize zbog klađenja na neke valute kao, npr., ona koja se desila na

\footnotetext{
${ }^{15}$ El-Bar, El-Muhaddiratul-hatarud-daimu, str. 159, Darul-kalem, 1408. po H./1988. god.

${ }^{16}$ El-Mevsuatul-fikhijje, 17/140.

${ }^{17}$ Zehebi, Kitabul-kebair, str. 100. Daru mektebetil-hajati littiba'ati ven-nešri, Bejrut, 1998. god.
} 
svjetskim burzama 1998. godine kao i ona u jugoistočnim azijskim zemljama 1999. godine. $^{18}$

Kazna koja je propisana za zločin kocke je diskrecione prirode koju određuju nadležni sukladno prilikama i situaciji u kojoj se ona desi.

Neki islamski pravnici smatraju da samo pozivanje na kocku ili njeno prihvatanje bez činjenja obavezuje iskup - kefaret ili podjelu sadake, a njene konzumiranje žestoku kaznu. ${ }^{19}$

\section{4. - Zločin prevare i obmane i propisana sankcija}

Varanje, obmana i prevara su zločini koji dovode do bespravnog uzimanja tuđeg imetka, uzrokuju anarhiju u međuljudskim odnosima, te slabe povjerenje među ljudima, a ponekad mogu dovesti i do uništenja života i imovine.

Sve vrste i oblici varanja su $\mathrm{u}$ islamu zabranjeni jer predstavljaju nepravdu i nasilje sukladno riječima Uzvišenog: A odgovaraće oni koji ljude tlače $i$ bez ikakva osnova red na Zemlji remete; njih čeka bolna patnja. (Ě̌-Šura, 42) A Poslanik, a.s., je rekao: „Ko nas vara nije od nas." (Muslim, br. 146)

Obmana i varanja dovode do ekonomskog nereda koji implicira štetu i dezorijentiranost, naročito ako se to varanje odvija na polju kvaliteta općenito, a posebno kvaliteta sirovina i tvari od kojih se pravi hrana, građevinski materijal, lijekovi itd.

Najpoznatiji savremeni oblici prevare, obmane i varanja su: prikrivanje nedostataka neke robe, miješanje kvalitetnoga s lošim, lažne reklame $\mathrm{i}$ spotovi, zaklinjanje i laganje itd. Navedene metode i njima slične dovode do bespravnog uzimanja tuđe imovine.

Kazne koje su propisane za varanje, obmanu, lažno predstavljanje i reklamiranje i prevaru su fiksne za krađu i diskrecione shodno onome

18 Šehate, El-Menhedžul-islami li tešhisi ve mu'aledžetil-ezemati fi sukil-evrakilmalijjeti, rad objavljen u časopisu El-Iktisadul-islami, broj. 216., 1420.po H/1999. god. Fejjad, Sukul-evrakil-malijjeti fi mizanil-fikhil-islami, Darun-nešri lil-džami'ati, Misr, 1418. po H./1998. god.

${ }^{19}$ Zehebi, Kitabul-kebair, str. 100. Daru mektebetil-hajati littiba'ati ven-nešri, Bejrut, 1998. god. 
kako procijene nadležni na osnovu stanja i prilika. Također je neophodno vratiti oduzeta prava putem navedenih nedozvoljenih radnji onima kojima pripadaju. A ugovori koji su zaključeni posredstvom istih se poništavaju.

Islamski pravnici su saglasni da su varanje, obmana, prevara itd. Jedna vrsta pronevjere emaneta koje implicira nasilje i poništenje berićeta.

\section{5. - Zločin zakidanja na mjerama i propisana sankcija}

Zakidanje na mjerama i proizvodnja roba i ostalih proizvoda i usluga suprotno propisanim standardima, mjerilima i sastavu smatra se jednom vrstom nasilja i agresije na tuđu imovinu što ima za posljedice podizanje berićeta. ${ }^{20}$

Islam je strogo zabranio zakidanje prilikom mjerenja i žestoko zaprijetio svim onima koji to prakticiraju.

Uzvišeni je rekao: Teško onima koji pri mjerenju zakidaju, koji punu mjeru uzimaju kada od drugih kupuju, a kada drugima mjere na litar ili na kantar - zakidaju. Kako ne pomisle da će oživljeni biti na Dan veliki, na Dan kada će se ljudi zbog Gospodara svjetova dići! (ElMutaffifin, 1-6)

Allah je kaznio Šuajbov narod teškom sušom i razornim zemljotresom jer se nisu odazvali svom Poslaniku kada im je rekao: I Medjenu - brata njihova Šuajba. "O narode moj" - govorio je on - "Allahu se klanjajte, vi drugog boga osim Njega nemate, i krivo na litru i na kantaru ne mjerite. Vidim da u obilju živite i bojim se da vas jednog dana ne zadesi kazna, pa da svi nastradate. O narode moj! Pravo mjerite $i$ na litru $i$ na kantaru i ne zakidajte ljudima stvari njihove i ne činite zlo po Zemlji praveći nered. (Hud, 84-85)

Poslanik, a.s., je, također, upozorio na kobne posljedice koje će osjetiti oni koji budu zakidali na mjerama rekavši: „Kad god neki narod počne zakidati na litru i kantaru Allah će ga kazniti sa sušom, sa glađu i sa nepravednim vladarom.“ (Ibn Madže, br. 4019, Bezzar i Bejheki); „Allah je u imecima bogatih odredio onoliko koliko je dovoljno

20 Šehate, El-Erzaku bejne bereketit-ta'ati vemhakis-seji'at, str. 136, 1421. po H../2000. god. 
siromašnim. Siromasi su gladni i neodjeveni samo zbog prakse bogatih. Allah će bogate sigurno ispitati na težak način i bolno ih kazniti." (Taberani, M'udžemus-sagir, str. 91, Ebu Ubejd, El-Emval, br. 1909, i Bejheki)

Kazna koja je propisana u šerijatu za ovu vrstu zločina pored navedene kosmičke je diskreciona čiju visinu i vrstu određuju nadležni sukladno vremenu, prilikama i okolnostima u kojima se on počini.

\section{6. - Zločin nedavanja zekata i propisana sankcija}

Nedavanjem zekata nastaje opći poremećaj i nered u društvu i zajednici, a posebno se to odražava na ekonomski segment, što ima za posljedicu uskraćivanje siromasima i nevoljnicima osnovnih ljudskih prava i produbljivanje njihova teška stanja.

Pored toga se opet na drugoj strani formira duboko raslojavanje društva u kom se stvara stalež enormno bogatih koji žive u raskoši, izobilju, rasipništvu, nadmenosti i oholosti. Tako nastaje bipolarno društvo s dva ekstremno suprotna staleža - na jednoj strani su oni koji nemaju ni za osnovne životne potrebe, a pored njih su oni koji se guše u izobilju, bogatstvu i rasipništvu. Upravo je to najopasniji i najočitiji oblik ekonomskog nereda $\mathrm{i}$ imovinske nepravedne raspodjele $\mathrm{u}$ jednom društvu.

Islamski učenjaci su saglasni da svaki musliman koji negira obaveznost zekata izlazi iz vjere i postaje nevjernik, a onaj koji tu obavezu prizna, ali odbija njegovo izdvajanje kažnjava se, a po nekim pravnim mišljenjima od njega se uzima zekat silom i konfiskuje mu se pola imovine. U tom smislu Poslanik, a.s., je rekao: „Onaj ko dadne zekat nadajući se nagradi biće zbog toga nagrađen. A ko ga odbije dati, uzeće se od njega silom i još pola njegove imovine. To je odluka našeg Gospodara i Muhammed po tom pitanju nema nikakvog prava.“ (Ahmed, br. 20016, Nesai, br. 2444. Ebu Davud, br. 1575)

Negator zekata ima status otpadnika od vjere pa se nad njim primjenjuju propisi koji tretiraju status otpadnika, a onaj koji ga priznaje kao Božiju naredbu, ali je odbija izvršiti, zekat se od njega uzima silom i kažnjava se diskrecionom kaznom pa makar to ponekad zahtijevalo i 
objavljivanje rata protiv takvih kako je to uradio Ebu Bekr, r.a., s onima koji su ga odbila dati. ${ }^{21}$

\section{Drugi dio}

\section{Metodologija islama u borbi protiv imovinsko-ekonomskog kriminala i njegova preveniranja}

Čovjek koji nije profiliran u vjerskom, moralnom i etičkom smislu je temelj ekonomsko-imovinskog kriminala, jer kada se pokvare ljudi pokvarit će se i odnos prema imovini pa će se zbog toga pojaviti i raširiti ekonomska nepravda sa svim svojim oblicima i finesama.

$\mathrm{Na}$ osnovu navedenih činjenica, islam nudi svoj program reforme ekonomije i ekonomske nepravde koja je danas pogodila cijelo čovječanstvo fokusirajući se pritom na duhovnu, odgojnu i moralnu dimenziju, te primjenu propisa i principa šerijata a posebno univerzalnu pravdu i njenu primjenu na svim segmentima ljudskog života naročito ekonomskog.

Taj program borbe protiv ekonomskog kriminala i njegove prevencije se može sažeti u sljedećem:

Prvo - duhovnim odgojem koji treba da počiva na vjerovanju, bogobojaznosti, svijesti, samokontroli i iskrenosti prema Allahu kao i neupitnom vjerovanju da je primjena šerijata najveći stepen ibadeta $\mathrm{i}$ jedna od vjerskih obaveza. Uzvišeni je rekao: $A$ da su stanovnici sélā $i$ gradova vjerovali i grijeha se klonili, Mi bismo im blagoslove i s neba i iz zemlje slali, ali, oni su poricali, pa smo ih kažnjavali za ono što su zaradili. (El-'Araf, 96)

Drugo - pridržavanjem lijepa morala i etike jer nema pravedne ekonomije bez morala. Najveći dokaz za to je što većina ajeta koji govore direktno ili indirektno o ekonomskim principima uporedno s njima tretira moralne principe i načela kao npr.: $O$ vjernici, zapišite kada jedan od drugog pozajmljujete do određenoga roka. I neka jedan pisar između vas to vjerno napiše i neka se pisar ne uzdržava da napiše, ta Allah ga je poučio; neka on piše, a dužnik neka mu u pero kazuje $i$

${ }^{21}$ Karadavi, Fikhuz-zekat, 1/78., 8. izdanje, Muessesetur-risale, Bejrut, 1405. po H./1985. god. 
neka se boji Allaha, Gospodara svoga, i neka ne umanji ništa od toga. (El-Bekare, 282)

Poslanik, a.s., je rekao: „Iskren i pošten trgovac će na Sudnjem danu biti u društvu poslanika, iskrenih i šehida.“" (Tirmizi, br. 1209, hasen)

Treće - primjenom ekonomsko-imovinskih Allahovih naputa i uputa Poslanika, a.s., koje su u biti temelj islamske ekonomije i u isto vrijeme i ekonomske reforme današnjeg savremenog ekonomsko-svjetskog sistema koji počiva na kamati i ostalim ekonomskim špekulacijama. To potvrđuje sljedeći ajet: A onaj ko okrene glavu od Knjige Moje, taj će teškim životom živjeti i na Sudnjem danu ćemo ga slijepim oživiti. "Gospodaru moj", - reći će - "zašto si me slijepa oživio kada sam vid imao?" "Evo zašto" - reći će On: "Dokazi Naši su ti dolazili, ali si ih zaboravljao, pa ćeš danas ti isto tako biti zaboravljen." (Taha, 124126)

Poslanik, a.s., je također rekao. „Ostavio sam vam dvije stvari kojih ako se budete pridržavali nikada nećete zalutati: Allahovu knjigu i moju praksu - sunnet.“(Malik, El-Muvetta, 2/899, Albani, Sahihut-tergib, br. 40)

Četvrto - dosljednom primjenom kazni koje je islam propisao za sve one koji počine bilo koji oblik ekonomsko-imovinskog kriminala što je $\mathrm{u}$ isto vrijeme i potvrda čvrstine vjerovanja i vjerske svijesti, jer se reforma ljudi vrši putem vjerovanja - imana, a države putem vjerozakona - šerijata.

Peto - selekcijom službenika i namještenika na osnovu znanja, stručne kompetentnosti i morala, a ne na osnovu rodbinskih, ideoloških, partijskih, jaranskih i bilo kojih drugih rezona, jer je to temelj djelotvorne i učinkovite prevencije protiv svake vrste ekonomskog kriminala koju treba primijeniti prije nego što se on desi. Ta pravila su se primjenjivala i na početku islama pa je ekonomski kriminal u potpunosti iskorijenjen ili je sveden na minimum.

Šesto - uzoritošću u primjeni islamskih propisa i načela, jer ukoliko odgovorni budu uzorni, i podanici će se neminovno povesti za njima, a prije svega toga učenjaci su ti koji moraju biti principijelni, nepotkupljivi i u svakoj prilici i situaciji stati uz pravdu i istinu bez obzira na posljedice, jer posrtaj učenjaka je propast svijeta i ummeta. U 
tom smislu imam Gazali je rekao: „Pokvarenost naroda je zbog pokvarenosti vladara. Pokvarenost vladara je zbog pokvarenosti učenjaka, a da nije pokvarenih sudija i učenjaka smanjila bi se pokvarenosti i vladara.“ 22

Prema tome, imam Gazali implicitno ukazuje na to da su za svu nepravdu, nerede i pokvarenosti u državi i društvu prije svega i pored ostalog krivi i odgovorni vjerski učenjaci koji su vjeru, pravdu i istinu prodali za ovosvjetske šićare i na taj način iznevjerili emanet znanja pa se njihova pokvarenost reflektovala na sve ostale nivoe države i društva.

\section{Umjesto zaključka}

U ovoj studiji smo elaborirali neke oblike ekonomsko-imovinskog kriminala koje je islam strogo zabranio prije više od četrnaest stoljeća. Utvrđeno je da njihova primjena dovodi do ataka i agresije na imovinu, živote, državu, društvo i javni red. Islam je navedeni kriminal zabranio zbog zaštite i očuvanja ljudskih prava i to mnogo prije nego što su donesene međunarodne konvencije o ljudskim pravima i slobodama.

Studija je kroz elaboraciju navedenih oblika ekonomskog kriminala utvrdila da njihova pojava i primjena u svakom društvu ostavlja katastrofalne posljedice kako na pojedinca, tako i na državu i društvo.

Najpoznatije posljedice ekonomskog kriminala su: nepravda, raslojavanje društva, ekonomsko tlačenje i porobljavanje, poremećaj u ekonomskom poslovanju, gubljenje povjerenja među ljudima, opasne svjetske ekonomske krize, nestanak kvaliteta, odstupanje od utvrđenih standarda i pravila, poigravanje za mjerama, štampanje papirnatog novca bez pokrića zlatom što na kraju ima za posljedicu društveno nasilje i podizanje revolucija od strane gladnih i tome slično.

Islamski program borbe i prevencije protiv navedenih oblika ekonomskog kriminala može se sažeti u sljedećem:

- imansko-moralni odgoj i uzorni karakter,

- primjena šerijatskih propisa i načela,

${ }^{22}$ El-Gazali, Ihjau-'ulumid-din, 2/357., Darul-fikri, Bejrut, Liban, 1989. god. 
- selekcija i imenovanje službenika i namještenika na osnovu imanskomoralnih vrijednosti, stručne kompetencija,

- primjena sankcija koje je islam propisao za one koji počine bilo koji ekonomski kriminal i na taj način ustanu protiv zakona $\mathrm{i}$ javnog reda $\mathrm{u}$ državi i društvu,

- praktični primjer - uzor u dosljednosti i poštenju od strane liderstva i onih koji obnašaju javne funkcije,

- temeljita reforma medija koji promovišu nemoral i nered u društva kako ne bi rušili ono što grade reformatorske snage,

- sukcesivnost u reformi i

- klonjenje koliko god je to moguće smutnje i nereda u državi i društvu.

Primjena navedenog programa zahtijeva veliki napor, snagu, upornosti i strpljivost sukladno riječima Uzvišenog: $O$ vjernici, budite strpljivi $i$ izdržljivi, na granicama bdijte i Allaha se bojte, da biste postigli ono što želite! (Ali Imran, 200)

\section{Popis literature}

Abdulkadir Avdeh, Et-Tešri'ul-džinail-islami mukarenen bil-kanunil-ved'i, muessesetur-risale, 7. izdanje, 1406. h. /1986. god.

El-Bar, El-Muhaddiratul-hatarud-daimu, Darul-kalem, 1408. h./1988. god.

Izduddin Belik, Minhadžus-salihin, babu hududillahi ve himajetil-mudžteme'i, Darul-fethi, Bejrut, 1398. h./1987. god.

Fejjad, Sukul-evrakil-malijjeti fi mizanil-fikhil-islami, Darun-nešri lildžami'ati, Misr, 1418. h./1998. god.

El-Gazali, Ihjau-'ulumid-din, Darul-fikri, Bejrut, Liban, 1989. god.

Gazi, Inajeh, El-Malijetul-ammetu ven-nizamul-malil-islami, dirasetun makarentun, Darul-džejl, Bejrut, 1410. h./1990. god.

Karadavi, Fikhuz-zekat, dirasetul-mukarene li ahkamiha ve felsefetiha fi dav'il-Kur'ani ves- sunneti, 8. izdanje, Muessesetur-risale, Bejrut, 1405. h./1985. god.

Ibn Kudame, El-Mugni, 10/264., prvo izdanje, Darul-fikri, Bejrut, 1984. god.

Muhhamed, Abdulhalim, Omer, Er-Rekabetu alel-emvalil-ammet, Tidžaretulezher, 1979. god. 
Seyyid, Qutb, U okrilju Kur'ana, 3/88-89. Fakultet islamskih nauka, Oko Sarajevo, 1997. god.

Serahsi, El-Mebsut, Darul-m'arife, Bejrut.

Šehate, El-Menhedžul-islami li tešhisi ve mu'aledžetil-ezemat fi sukil-evrakilmalijjeti, rad objavljen u časopisu El-Iktisadul-islami, broj. 216., 1420.h/1999. god.

Šehate, El-Erzaku bejne bereketit-ta'ati vemhakis-seji'at, 1421. h./2000. god.

Vizaretu-evkafi ve šu'unil-isamijje, El-Mevsuatul-fikhijje, drug izdanje, 1990./1410. h.

Zehebi, Kitabul-kebair, Daru mektebetil-hajati littiba'ati ven-nešri, Bejrut, 1998. god. 


\author{
Sulejman Topoljak, PhD \\ University of Bihac \\ Islamic Pedagogical Faculty \\ E-mail: sulejman.topoljak@,hotmail.com
}

\title{
ECONOMIC AND PROPERTY CRIME IN ISLAM
}

\section{ABSTRACT}

Property and the economy are the basic needs of every individual, community, society and state and also their backbone. Therefore, Islam classified property into five universal values, protected them with its norms and regulations and determined sanctions against anyone who threatens, devalues and destroys them in any way, because their protection in the same time protects the individual, family, society and public order in the country, even the state itself.

Property and economy in every society and state have the status of bloodstream in a living organism - the body. In order for the body to be bealthy and able to perform its basic function, it is necessary to have a bealthy blood circulation. Healthy bloodstream means healthy and clean veins, arteries and capillaries so that the blood can reach and bring oxygen and food to every cell and capillary in the body. Any narrowing or blockage in these conductors would have undesirable consequences that will affect the normal functioning of the body and possibly cause its death. The same logic and analogy should be used to observe at property and the economy in one society and state. If property does not reach every citizen in society and communities in healthy and unclogged ways, but accumulates in the hands of individuals or privileged groups and oligarchy, the bloodstream of such society and state will become sick and clogged and such state and society will not be able for normal functioning and then it's only a matter of days before it gets a heart attack or stroke and be left crippled, completely paralyzed or destroyed.

Hence, the aim of this study is to examine the position of Islam on the issue of economic and property crime and the preventive measures it prescribed in order to protect and preserve that bloodstream due to its fateful and unavoidable importance in the life of an individual and in the survival of every society and state. The current disruption of the property and economic system, i.e. the economic bloodstream at the macro and micro level, confirms the importance of its protection and health, otherwise, the consequences of its disease and blockage will affect almost every country and every resident of this planet. This confirms the current economic situation in the world and all the consequences which it has caused and brought. 
The paper will list the most important types of that crime, the sanctions that have been prescribed, the benefits that are realized from the using those sanctions, and the preventive - reform program that Islam has prescribed for the protection of the economy and its revitalization.

Key words: Islam, crime, sanction, struggle, prevention, property, program 
الأستاذ الدكتور سليمان توبولياك

جامعة بيهاتش

كلية التربية الإسلامية

sulejman.topoljak@hotmail.com

\section{الجرائم الاقتصادية والُلكية في الإسلام}

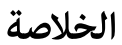

تعتبر الأملاك والاقتصاد من الحاجات الأساسية لكل فرد ومؤسسة، ولكل مجتمع ودولة وهي ألإني

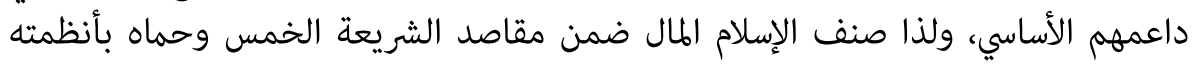

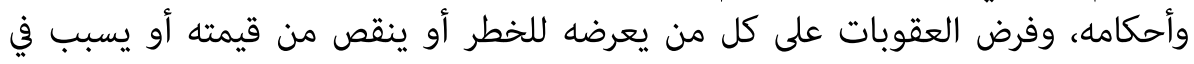

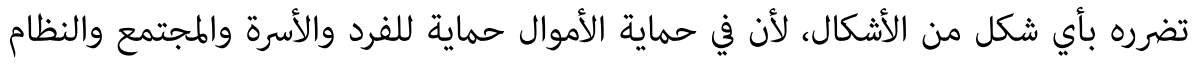
العام في الدولة وحتى الدولة نفسها.

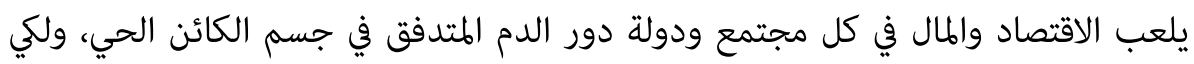

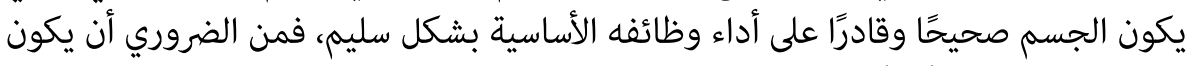

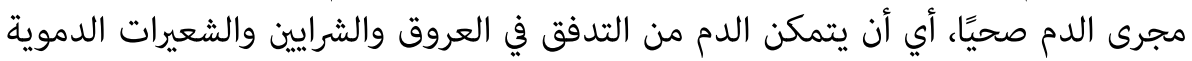

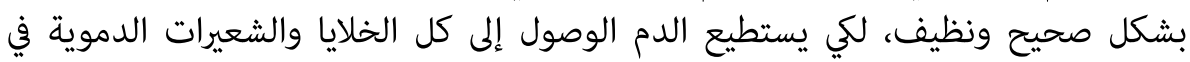

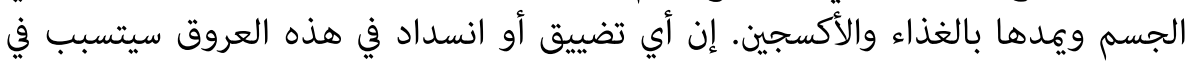

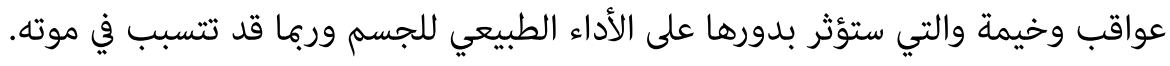
قياسًا على ذلك ننظر إلى الأملاك والاقتصاد في المجتمع والدولة، فإذا لم تصل الأموال المستحقة

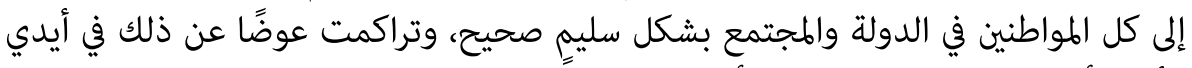

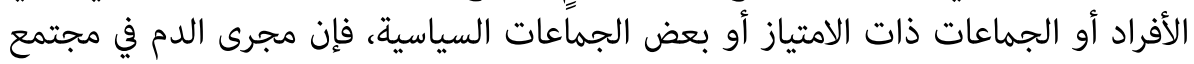

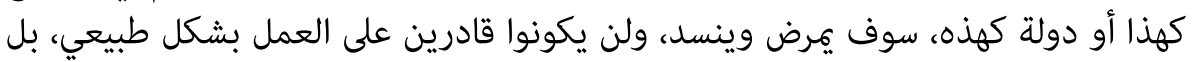

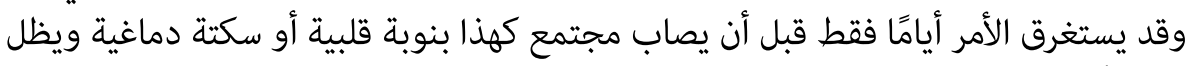

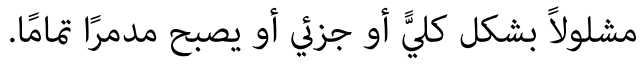

لذلك تهدف هذه الدراسة إلى التحقيق في موقف الإسلام من قضية الجرائم الاقتصادية

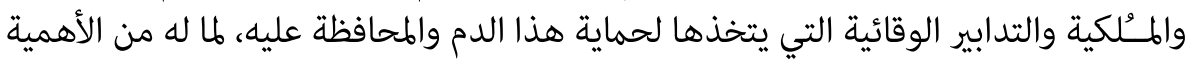

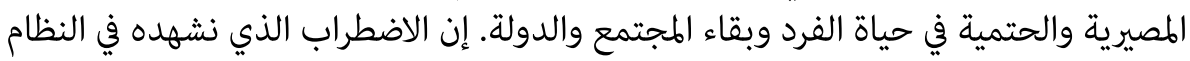

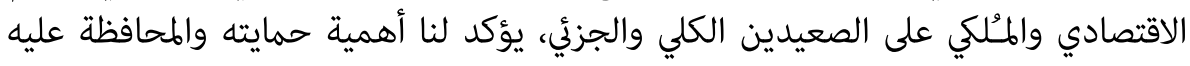
سليمًا، وإلا فإن عواقب مرضه وانسداده ستكون خطيرة على المستوى العام لكل دولة تقريبًا، 
وسيتأثر بها جميع سكان هذا الكوكب. إن الوضع الاقتصادي العالمي الراهن أكبر دليل على الى إنى هذه العواقب الكارثية الوخيمة.

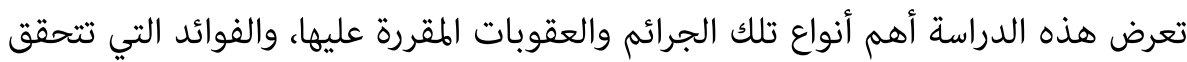

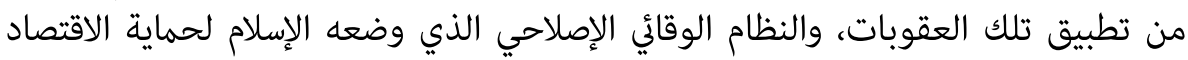
وتنشيطه. الكلمات المفتاحية: إسلام، جرائم، عقوبات، محاربة، وقاية، أملاك، نظام. 